\title{
DEMOGRAFICKÝ VÝVOJ VENKOVSKÝCH OBLASTÍ JIHOMORAVSKÉHO KRAJE
}

\section{DEMOGRAPHIC DEVELOPMENT IN RURAL AREAS OF THE SOUTH MORAVIAN REGION}

\section{ING. ONDŘEJ PETR}

\author{
Katedra regionální ekonomie a správy $\mid$ Dep. of Regional Economics and Administration \\ Ekonomicko-správni fakulta Faculty of Economics and Administration \\ Masarykova univerzita Masaryk University \\ $\triangle$ Lipová 4la, 60200 Brno, Czech Republic \\ E-mail: ondrej.petr@mail.muni.cz
}

\begin{abstract}
Anotace
Článek se zabývá problematikou demografického vývoje venkovských oblasti Jihomoravského kraje. Úvodni část nabizi stručný přehled východisek zkoumané problematiky, kterou následuji výsledky zpracováni vývojových trendỉ vybraných demografických charakteristik na úrovni obci v obdobi 1991 - 2011, na jehož základě je vyhodnocena regionálni diferenciace demografického vývoje venkovských oblastí Jihomoravského kraje. Zajímavých výsledků je dosaženo zejména v souvislosti s kategorizací venkovských obci dle intenzity vyjizźd'ky do zaméstnání.
\end{abstract}

\section{Klíčová slova}

Venkovské oblasti, demografický vývoj, zázemi měst, vyjižd'ka, regionální diferenciace, Jihomoravský kraj.

\section{Annotation}

The paper deals with the demographic development in rural areas of the South Moravian Region. The introductory part presents an overview of the departure points for our research. It is followed by the results of a study of development trends in selected demographic characteristics at the municipal level, concerning the period 1991-2011. Based on this study, the regional differentiation of demographic development in rural areas of the South Moravian Region is established. Interesting results have been obtained especially as regards the classification of rural settlements according to the intensity of commuting to work.

Key words

Rural Areas, Demographic Development, Suburb, Commuting, Regional Differentiation, Southern Moravia.

JEL classification: $J 11$

\section{Úvod}

Obyvatelstvo je základním parametrem, který vstupuje do všech oblastí společenského života. Lidská práce je jedním ze základních výrobních faktorů a lidské potřeby jsou zároveň zdrojem poptávky po statcích a službách, at' už je tato poptávka směřována $\mathrm{k}$ soukromému či veřejnému sektoru hospodářství, jehož fungování demografický vývoj zásadním způsobem předurčuje. Venkovské oblasti podle statistických či administrativních kritérií, standardně užívaných v podmínkách České republiky, představují až 90 \% všech obcí ČR, více než tři čtvrtiny rozlohy jejího území a žije v nich přibližně čtvrtina jejích obyvatel (dle Sčítání lidu, domů a bytů 2001). Problémem většiny vyspělých zemí, který je v př́padě venkovských oblastí často vnímán palčivěji, jsou v posledních desetiletích 
záporné hodnoty přirozeného pohybu obyvatelstva, způsobené nízkou úrovní úhrnné plodnosti, která nezajištuje prostou reprodukci obyvatel a spolu s prodlužováním střední délky života vede ke stárnutí populace a rostoucí zátěži sociálního systému (např. Petr, 2010).

Cílem studie, jejíž výsledky jsou prezentovány $\mathrm{v}$ tomto článku, je analýza regionální diferenciace demografického vývoje venkovských oblastí Jihomoravského kraje, která s ohledem na velikost venkovského prostoru a dynamiku (ze své povahy prostorově selektivních) procesů urbanizace a suburbanizace zcela jistě existuje.

V souvislosti s regionální diferenciací demografického vývoje je třeba vzít na vědomí, že vznik regionálních disparit obecně je doprovodným jevem procesů př́rodní i společenské evoluce, přičemž nelze jednoznačně říci, zda je existence disparit pozitivní či nikoliv (Viturka, 2010). Demografické stárnutí a vylidňování určitých oblastí může být $\mathrm{v}$ jistém smyslu vnímáno pozitivně, jako projev efektivní alokace zdrojů. Jelikož je však podle Viturky (2010) nutné rozvoj každé společnosti usměrňovat a vznikající disparity udržovat $\mathrm{v}$ určitých mezích, převážně je tento problém vnímán negativně, jako jedna z příčin úpadku periferií, prohlubování regionální diferenciace a narušování komplexního rozvoje území ČR zaostávajícími oblastmi. Vzhledem k tomu, že k migraci nejčastěji tendují mladí a vzdělaní lidé, jejich odchod se výrazně promítá i do přirozeného populačního vývoje venkova.

\section{Teoreticko-metodologická východiska}

Zásadním a nezbytným krokem zpracování této studie, $\mathrm{k}$ němuž v odborné literatuře existuje poměrně bohatá diskuze, je vymezení venkovského prostoru. Vymezením a kategorizací venkovského prostoru se zabývá např. Cloke (1977), na kterého později navazuje Robinson (1990). Oba autoři vnímají nesourodost venkovského prostoru, zejména rozdíly mezi venkovem príměstským a periferním. Patmore (1983) nevidí mezi městem a venkovem existenci ostré hranice, cítí spíše kontinuitu v rámci prostoru - všechno je součástí harmonického, komplexního, funkčního celku (srov. s Green, 1990). Vaishar a kol. (2008) uvádí, že v našich podmínkách se v současnosti rozdíly mezi městským a venkovským způsobem života stírají. Scharf (2001) upozorňuje na skutečnost, že rozdíly mezi městskými a venkovskými oblastmi bývají obecně zveličovány, přičemž mnohem větší rozdíly existují např. mezi západní a východní částí Německa. Robinson (1990) i Hoggart (1990) upozorňují na špatnou definiční uchopitelnost pojmu „venkovský“, zejména z důvodu heterogenity venkovského prostoru a řady podobností mezi venkovem a městem. Dle Cloka (1992) lze dokonce venkovský prostor chápat ve smyslu jeho vnímání návštěvníky pouze jako sociální konstrukt, čehož využívá např. marketing cestovního ruchu. Venkov je obecně vymezován jako řídce osídlený prostor, ve kterém má důležitou funkci zemědělství. Může být vymezen pozitivně nebo negativně, tedy jako doplněk městských struktur, území mimo plochy měst. Subjektivně může být vymezen např́klad na základě vyjádření místních obyvatel o svém sídle, jejich dojmů a cítění. V rámci objektivních prrístupů $\mathrm{k}$ identifikaci venkova je nutné brát v úvahu její účel, př́ípadně obor, který se o problematiku zajímá. Dle Perlína (1998) bývají často rozlišována následující hlediska vymezení venkovského sídla: urbanistické, architektonické, sociologické, ekonomické, historické, administrativní a statistické. Z důvodu uchopitelnosti dat jsou venkovské oblasti nejčastěji vymezovány na základě kritérií statistických nebo administrativních - počtu obyvatel obce, statutu a hustoty obyvatel.

Demografické změny, odehrávající se v demokratické Evropě již od 60. let 20. století, se v ČR plně projevily až o třicet let později. Rychlost těchto změn byla umocněna probíhající transformací ekonomického i politického prostředí (Burcin a kol. 2010), a také přicházející globalizací a přejímáním zahraničních vzorců chování (Kornai 2006). Vývoj hospodářsko-politických podmínek se v České republice výrazně projevil také v př́ípadě demografického vývoje venkovských oblastí. Pavlík a kol. (1986: 472) si všímá skutečnosti, že „...v demografii se tradičně věnuje pozornost rozložení obcí na venkovské obce a na městské obce, charakter demografické reprodukce se zejména v dobách významných změn $\mathrm{v}$ této reprodukci značně lišil u městského a venkovského obyvatelstva“. Vylidňování venkovských oblastí ČR se věnují např. Maryáš a Řehák (1990). Kolektivizace a mechanizace zemědělství způsobila na venkově přebytky pracovní síly, zatímco rozvíjející se průmysl 
lákal lidi za prací do měst. Po několik dekád vnitřní stěhování probíhalo především ve znamení urbanizace a odlivu zejména mladých lidí z venkova (o významu lidských zdrojů pro rozvoj menších obcí se zmiňuje např. Pařil, 2010). Rozvoj prostorové mobility obyvatel, materiálu a informací, jdoucí ruku $\mathrm{v}$ ruce $\mathrm{s}$ rozvojem měst, získával $\mathrm{v}$ průběhu 90 . let jiný charakter a posunul se směrem propojovacím, integračním - převážně jednostranná industriální orientace pohybů je nahrazována oboustrannou interakcí mezi jádrem a zázemím (Hampl 2005). Jak uvádí Burcin a kol. (2010), koncentrační tendence začaly $\mathrm{v} 90$. letech přecházet $\mathrm{v}$ tendence dekoncentrační a suburbanizace se začala projevovat silněji. Projevům suburbanizace a jejich stupňování po roce 1990 se blíže věnují také Kunc a Synková (2010). V souhrnu sice dochází k populačnímu růstu venkova, ale př́městský venkov, který získává nejvíce obyvatel, má dnes sotva charakter venkova (Perlín 1998, Binek a kol. 2007). Obyvatelstvo odlehlých venkovských oblastí, vzdálených od ekonomických a správních center, se špatnou dopravní dostupností a nedostatkem pracovních př́ležitostí, dále ubývá či stagnuje (Burcin a kol. 2010). Bevan (2009) zmiňuje na př́kladu Anglie, že venkovských oblastí se stárnutí obyvatel týká ve znatelně větší míře, než městských oblastí, přičemž i v dalších zemích platí, že podíl starších věkových skupin roste ve venkovských populacích rychleji než v městských. Scharf (2001) uvádí, že úhrnná plodnost je sice v Německu tradičně vyšší na venkově než ve městech, ale vliv migrace, která ve znamení suburbanizace způsobuje stárnutí obyvatel $\mathrm{v}$ odlehlejších venkovských oblastech a současně v centrech velkých měst, je silnější.

V rámci výzkumu je věnována pozornost vývoji počtu obyvatel a věkové struktury ve venkovských oblastech Jihomoravského kraje (1991 - 2011). Věková struktura je zachycena prostřednictvím indexu stáří jakožto podílu počtu obyvatel ve věkových skupinách 65+ a 0-14 let (x 100), případně prostřednictvím podílu jednotlivých věkových skupin na sledované populaci. Aby bylo možné věnovat se prostorové diferenciaci vývoje sledovaných veličin $\mathrm{v}$ čase, je nezbytné disponovat $\mathrm{v}$ každém sledovaném okamžiku srovnatelným souborem obcí jakožto základních prostorových jednotek shromažd'ování a především publikování dat ze strany ČSÚ. Bylo tedy nutné přepočítat veškerá data na územní strukturu, která byla tvořena nejnižším počtem obcí v rámci sledovaného časového období, přičemž tomuto stavu odpovídá rok 1991. K přepočtu bylo využito přehledu územních změn, zveřejněného ČSÚ v Databázi demografických údajů za obce ČR. Územní struktuře Jihomoravského kraje (dále JMK) roku 1991 odpovídá soubor 618 obcí, na němž došlo k vymezení venkova, sledování vývoje vybraných demografických ukazatelů v čase a zkoumání jeho prostorové diferenciace.

Ze základních kritérií vymezení venkova se vzhledem $\mathrm{k}$ délce sledovaného období a nesnadné dostupnosti dat jako nejpřijatelnější jeví statistické kritérium počtu obyvatel, přičemž $\mathrm{v}$ rámci této studie je venkov vymezen na základě počtu obyvatel dle SLDB 1991 za využití hranice 2000 obyvatel. Do kategorie obcí do 2000 obyvatel spadá 542 obcí, které reprezentují bezmála $88 \%$ celkového počtu obcí a téměř $28 \%$ celkového počtu obyvatel JMK. Je zřejmé, že vymezení venkova pouze na základě tohoto kritéria není vzhledem $\mathrm{k}$ existenci regionálních odlišností v sídelní struktuře plynoucích z rozdílného kulturně-historického vývoje ideální, což dokládá př́íklad okresů Břeclav a zejména Hodonín, pro něž je typický nižší počet větších venkovských obcí, obzvláště v kontrastu $\mathrm{s}$ osídlením Českomoravské, resp. Drahanské vrchoviny (zmiňuje např. Toušek a kol. 2006). Nutno však podotknout, že cílem článku není zpracovat precizní přístup k vymezení venkova, nýbrž věnovat se regionální diferenciaci demografického vývoje venkovských oblastí. Z tohoto pohledu lze „užši““ variantu vymezení venkova považovat za př́nosnější než variantu „zbytečně širokou“. Vymezení venkova je, obzvláště v Jihomoravském kraji, značně diskutabilní a téměř každá varianta je zatěžkána řadou pochybností (blíže rozvádí např. publikace ČSÚ Postavení venkova v Jihomoravském kraji, 2009). K okresům Břeclav a Hodonín je v průběhu zpracování výsledků přistupováno individuálně, a sice sledováním dat vybraných obcí až do hranice 4000 obyvatel.

Zvláštní pozornost je věnována rozdílům $\mathrm{v}$ demografickém vývoji venkovského zázemí měst a ostatních venkovských obcí. Vymezeno a analyzováno je pouze zázemí okresních měst jakožto nejsilnějších center Jihomoravského kraje. Dochází tak k uchopení prostoru, který se do jisté míry podobá suburbánní zóně, definované blíže napr. Perlínem (1998). Zázemí je identifikováno na základě rozsahu denní vyjížd’ky z venkovských obcí za prací do okresních měst (dále jen „,vyjížd’ka“) dle 
SLDB 2001. V úvahu je brán pouze nejsilnější proud vyjížd’ky z každé obce. Dochází tak k výběru obcí, které opravdu tíhnou $\mathrm{k}$ některému $\mathrm{z}$ okresních měst. Počet vyjíždějících denně za prací je vztažen $\mathrm{k}$ počtu trvale bydlících zaměstnaných, čímž oproti použití počtu ekonomicky aktivních ve jmenovateli dochází $\mathrm{k}$ eliminaci nezaměstnaných, potenciálně zkreslujících hodnoty zejména $\mathrm{v}$ nejmenších obcích.

\section{Výsledky}

Již z jednoduché analýzy vývoje počtu obyvatel dle vybraných velikostních kategorií obcí JMK je možné sledovat základní vývojové trendy. Obce s více než 2000 obyvateli vykazují v rámci sledovaného období dle tab. 1 mírně klesající vývojovou tendenci, obce do 2000 obyvatel jako celek naopak populačně výrazně rostou, dle Srba (2004) zejména zásluhou rostoucích migračních zisků od roku 1994, s dalším zrychlením suburbanizačních tendencí po přelomu tisíciletí. I v kategorii obcí do 2000 obyvatel však existují rozdíly. Zatímco obce kategorie 500 - 1999 obyvatel a $200-499$ obyvatel zaznamenaly výrazný relativní př́růstek počtu obyvatel, kategorie nejmenších obcí do 200 obyvatel ve zkoumaném období obyvatelstvo ztratila. Této kategorie se suburbanizace pravděpodobně dotkla opožděně a v omezené míre, která nestačila zvrátit vývoj počtu obyvatel za sledované období do kladných hodnot. Lze předpokládat, že se jedná o odlehlé obce s nižší atraktivitou pro práci a bydlení. Pro venkovské oblasti JMK je př́značná zrychlená dynamika vývoje počtu obyvatel v druhé dekádě sledovaného období, což souvisí s již zmiňovanou suburbanizací.

Tab. 1: Vývoj počtu obyvatel vybraných velikostních kategorií obcí JMK (1991-2011)

\begin{tabular}{|l|r|r|r|r|}
\hline Území & Počet obyvatel 1991 & Počet obyvatel 2001 & Počet obyvatel 2011 & $\begin{array}{c}\text { Změna počtu obyvatel } \\
1991-2011(\%)\end{array}$ \\
\hline Česká republika & 10302215 & 10230060 & 10562214 & 2,5 \\
\hline Jihomoravský kraj & 1136832 & 1127718 & 1157583 & 1,8 \\
\hline Obce s 2000 a více obyvateli & 821670 & 810603 & 818724 & $-0,4$ \\
\hline Obce s 0 - 1999 obyvateli & 315162 & 317115 & 338859 & 7,5 \\
\hline - z toho: 500 - 1999 obyvatel & 236208 & 239036 & 254912 & 7,9 \\
\hline - z toho: $200-499$ obyvatel & 66437 & 66264 & 71573 & 7,7 \\
\hline - z toho: 0 - 199 obyvatel & 12517 & 11815 & 12374 & $-1,1$ \\
\hline
\end{tabular}

Zdroj: ČSÚ - SLDB 1991, SLDB 2001, předběžné výsledky SLDB 2011, vlastní zpracování

Ze zkoumání souvislosti mezi průběhem demografického stárnutí a populační velikostí obce vyplývá, že čím jsou obce menší, s tím vyšší hodnotou indexu stáŕí vstupují do sledovaného období. Z vývoje během tohoto období (tab. 2) je patrné, že nejstabilnější věková struktura obyvatel je př́iznačná pro kategorii nejmenších obcí do 200 obyvatel, kdy proces stárnutí sice ve druhé sledované dekádě akceleruje, ale během celého sledovaného období se index stáří zvýšil relativně nejméně. U obcí kategorie 200 - 499 obyvatel lze pozorovat srovnatelnou hodnotu změny indexu stář́, ale naopak zde dochází ke zpomalení procesu stárnutí mezi lety 2001 a 2011. V obcích s 500 - 1999 obyvateli a ve městech probíhá proces stárnutí rovnoměrně, ovšem s nejvyšší hodnotou relativního růstu indexu stárí.

\section{Tab. 2: Vývoj indexu stář́ vybraných velikostních kategorií obcí JMK (1991-2011)}

\begin{tabular}{|l|c|c|c|c|}
\hline Území & Index stáři 1991 & Index stáří 2001 & Index stáři 2011 & $\begin{array}{c}\text { Změna indexu stáŕí } \\
1991-2011(\%)\end{array}$ \\
\hline Česká republika & 62,0 & 87,2 & 109,8 & 77,1 \\
\hline Jihomoravský kraj & 63,5 & 89,6 & 115,4 & 81,7 \\
\hline Obce s 2000 a více obyvateli & 61,1 & 91,8 & 122,3 & 100,2 \\
\hline Obce s 0 - 1999 obyvateli & 69,5 & 84,4 & 100,2 & 44,2 \\
\hline - z toho: 500 - 1999 obyvatel & 65,8 & 81,5 & 98,8 & 50,2 \\
\hline - z toho: 200 - 499 obyvatel & 78,2 & 90,7 & 101,1 & 29,3 \\
\hline - z toho: 0 - 199 obyvatel & 99,4 & 110,6 & 124,1 & 24,8 \\
\hline
\end{tabular}

Zdroj: ČSÚ - SLDB 1991, SLDB 2001, předběžné výsledky SLDB 2011, vlastni zpracování 
Nejstarší obyvatelstvo tedy v současnosti žije v nejmenších obcích, nicméně oproti městům se nejedná o nic nového. V obou těchto kategoriích dochází $\mathrm{k}$ výraznému úbytku dětské složky populace (města $34,5 \%$, obce do 200 obyvatel $-21,8 \%$ ) a mírnému nárůstu produktivního obyvatelstva (města 4,4 \%, obce do 200 obyvatel 5,2 \%). Věková skupina obyvatel starších 65 let však v nejmenších obcích mírně ztrácí $(-2,4 \%)$, ale ve městech prudce roste $(31,1 \%)$. To vysvětluje čtyřnásobně vyšší dynamiku růstu indexu stáríi v př́padě měst. Před rokem 1989 probíhaly přesuny obyvatelstva ve znamení urbanizace, tedy zejména $z$ venkova do měst či větších obcí za prací. Ve spojení se štědrou bytovou a rodinnou politikou tak města rostla - přicházeli zejména mladí lidé, kteří zakládali rodiny. Venkov současně ztrácel nejvíce perspektivní složky obyvatelstva. V 90. letech se však ke slovu začala dostávat suburbanizace, směřující ze zhoršujícího se prostředí měst do jejich zázemí, především do míst s dobrou dojížd'kovou vzdáleností za prací a vzděláním. Opět se stěhovali především lidé v produktivním věku, s dětmi nebo vizí rodiny (obecně platí, že k migraci tendují spíše mladí lidé). Na kategorii obcí do 2000 obyvatel je vidět, že díky tomu stále udržuje vyrovnané zastoupení předproduktivní a poproduktivní složky obyvatel, především zásluhou obcí v kategorii 200 - 1999 obyvatel. Nejmenší obce nejsou suburbanizací tolik zasaženy, což se odráží i na jejich věkové struktuře. Podobnému stavu se však obrovskou rychlostí přiblížila také města, jejichž index stáŕí se během sledovaného období zdvojnásobil.

Mnohem podrobnější pohled na změnu počtu obyvatel v rámci Jihomoravského kraje nabízí následující kartogram. Jako venkovské oblasti s největším nárůstem počtu obyvatel lze označit venkovské obce ležící v bezprostřední blízkosti města Brna (potažmo celý okres Brno-venkov, dokonce s přesahem východním směrem na Rousínov a Slavkov), a dále obce, které se nachází v okolí okresních měst Blanska, Vyškova a Znojma. Pozitivní populační vývoj lze pozorovat i ve venkovských obcích kolem Boskovic. Za povšimnutí stojí zejména severní až severovýchodní zázemí Brna, které se prolíná se zázemím Blanska a Vyškova, čímž vzniká oblast s vysokou intenzitou populačního růstu.

\section{Obr. 1: Vývoj počtu obyvatel ve venkovských obcích JMK (1991-2011)}

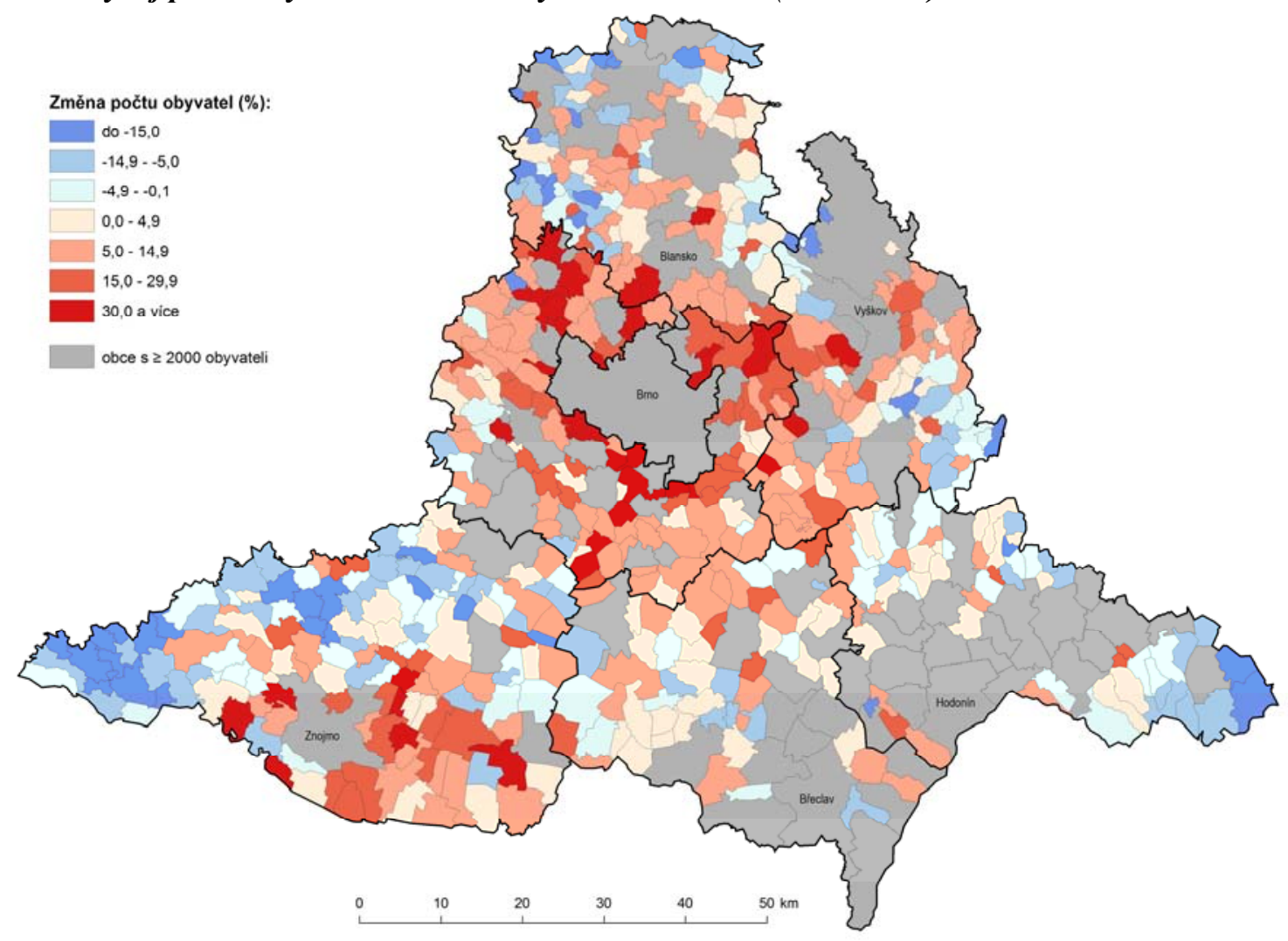

Zdroj: ČSÚ - SLDB 1991, SLDB 2001, předběžné výsledky SLDB 2011, vlastni zpracování 
Mezi venkovské oblasti, které jsou dle kartogramu nejvíce postižené úbytkem obyvatel, patří severozápad a západ okresu Blansko, severní a západní část okresu Znojmo (Vranovsko), jihovýchod okresu Vyškov (Bučovicko) a východní část okresu Hodonín - zejména správní obvod obce s rozšířenou působností (dále SO ORP) Veselí nad Moravou. Všechny uvedené oblasti se nachází při hranicích Jihomoravského kraje. Problém úbytku obyvatel se kumuluje zejména v okresu Hodonín, kde ztrácí jak venkovské obce do 2000 obyvatel $(-0,7 \%)$ tak i města $(-3,5 \%)$. Mezi prvními 100 venkovskými obcemi dle relativního nárůstu počtu obyvatel ve sledovaném období tvoř́ 51 obcemi většinu okres Brno-venkov, sporadicky jsou naopak zastoupeny okresy Břeclav (5 obcí) a Hodonín (3 obce). Na opačném konci žebříčku dominuje okres Znojmo, zastoupený 45 obcemi, a dále Blansko (28 obcí). Nejméně zastoupené jsou okresy Brno-venkov a Břeclav (po třech obcích).

Nejmladšími byly na počátku sledovaného období venkovské oblasti Znojemska a Břeclavska, kde svoji roli mohla sehrát tradice místní lidové kultury a křest’anství, ale také skutečnost, že se jedná o dosídlené oblasti, které si dle Čtrnácta a Maryáše (1993) obvykle zachovávají vysokou populační aktivitu po více generací. $K$ těmto dvěma okresům se v současnosti díky masivní suburbanizaci připojuje také venkovské zázemí Brna. Ze srovnání kartogramů indexu stáŕí v roce 1991 a 2011 (z důvodu rozsahu zde nefigurují) vyplývá zřetelný nárůst hodnoty indexu stáŕí v rámci celého sledovaného území. V roce 1991 byla nejstarší věková struktura charakteristická pro venkov severozápadní až západní části okresu Brno-venkov (Rosicko, Ivančicko, Tišnovsko), dále pro venkov západní části okresu Blansko (Tišnovsko, Blanensko), venkov východní části okresu Vyškov (Ivanovicko, Bučovicko), oblast pomezí okresů Vyškov a Hodonín a venkovské oblasti severní části okresu Znojmo. V roce 2011 se již s nepř́iznivou věkovou strukturou potýkaly i venkovské oblasti ve východních částech okresů Blansko a Hodonín (SO ORP Veselí nad Moravou), centrální části okresu Břeclav a v okrese Znojmo se oblast rozš́iřila směrem na západ na Vranovsko.

\section{Obr. 2: Změna indexu stáří ve venkovských obcích JMK (1991-2011)}

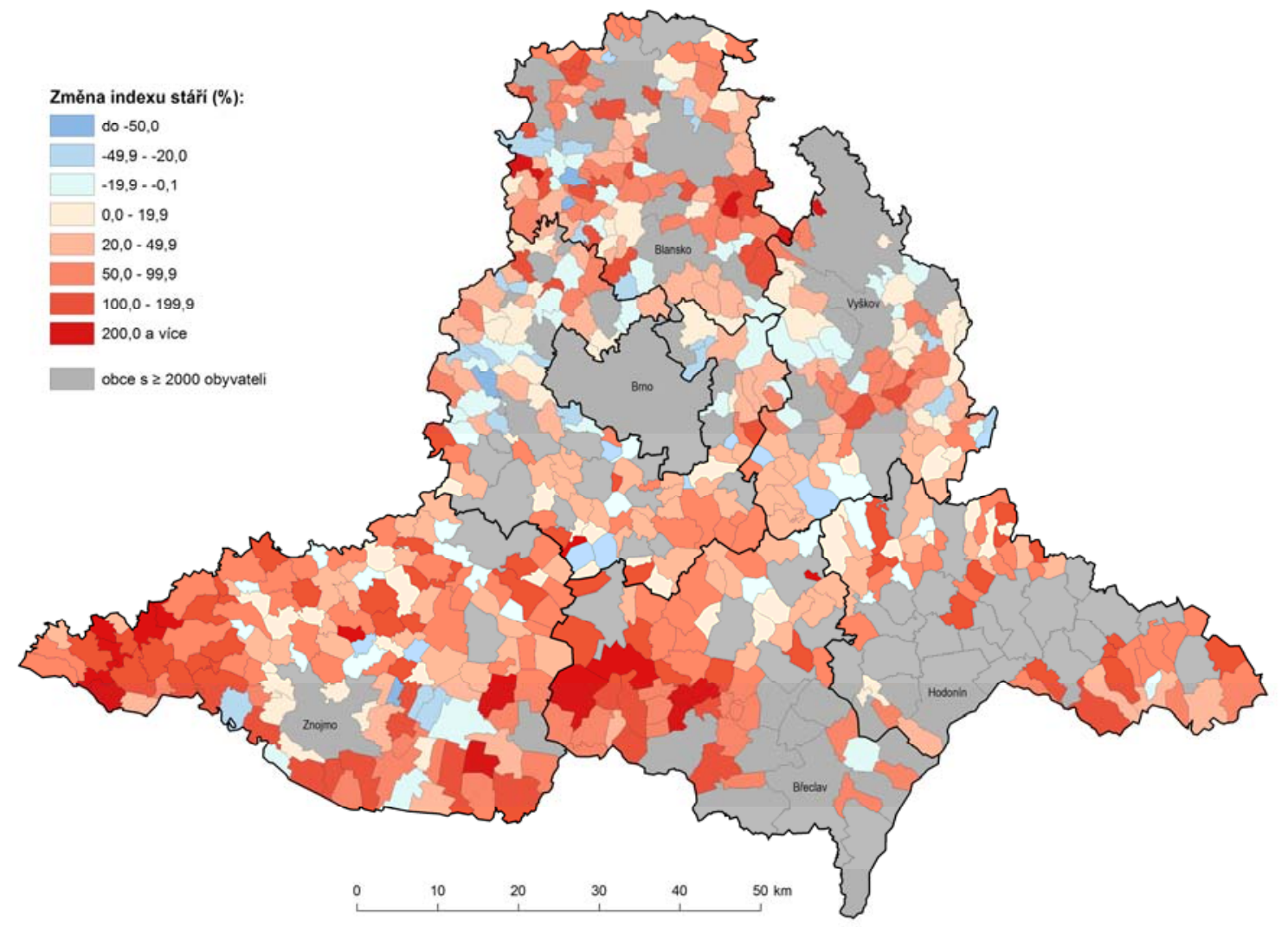

Zdroj: ČSÚ - SLDB 1991, SLDB 2001, předběžné výsledky SLDB 2011, vlastni zpracování

Za sledované období se nejvýraznější nárůst indexu stáŕí odehrál ve venkovském prostoru okresů Břeclav, Znojmo, Hodonín a Blansko. Jedná se zejména o západní polovinu okresu Břeclav, téměř 
celý okres Znojmo, přičemž nejvýrazněji zestárla jeho západní a jihovýchodní část, dále severní a jihovýchodní část okresu Hodonín a jihozápadní a východní část okresu Blansko. Obzvláště výrazná je však kumulace procesu demografického stárnutí v jižní části Jihomoravského kraje (obr. 2).

Pozornost byla věnována i obcím okresů Břeclav a Hodonín velikostní kategorie 2000 - 3999 obyvatel, což se týká 11 obcí okresu Břeclav a 14 obcí okresu Hodonín. Celkově tyto obce mezi lety 1991 a 2011 získaly 1,1 \% obyvatel a jejich index stáŕí vzrostl téměř dvojnásobně (o 95,2 \% $\mathrm{z}$ hodnoty 57,3 na hodnotu 111,8), přičemž vývoj této kategorie obcí je v př́padě obou okresů $\mathrm{v}$ souhrnu téměř shodný. S jistou mírou generalizace lze konstatovat, že rozsahem pozorovaných demografických změn mají obce okresů Břeclav a Hodonín velikostní kategorie 2000 - 3999 obyvatel velmi blízko městům Jihomoravského kraje v pojetí obcí se 2000 a více obyvateli, nechovají se jako ostatní venkovské obce Jihomoravského kraje a jejich oddělené sledování se ukazuje jako opodstatněné. Co se týče okresu Břeclav, lze tyto obce označit za populačně stagnující, s rozmezím relativní změny počtu obyvatel od $-1,4$ do $3,3 \%$. V okresu Hodonín je tento interval rozmanitější a rozmezí jeho hodnot je širší (od $-6,7$ do 10,4 \%), což signalizuje silnější prostorovou diferenciaci demografického vývoje. V souladu s výše uvedenou domněnkou je růst počtu obyvatel v bezprostředním okolí Hodonína ( $\mathrm{v}$ obcích Dolní Bojanovice, Josefov, Mikulčice, Mutěnice, Rohatec, Starý Poddvorov či Sudoměřce dosahuje relativní růst počtu obyvatel hodnot od 4,9 \% v Mutěnicích do 19,5 \% v Josefově). Obce okresů Břeclav a Hodonín kategorie 2000 - 3999 obyvatel spadaly v roce 1991 mezi nejmladší obce JMK, s hodnotami indexu stáŕí v rozmezí od 38,4 do 72,5. Tento interval se do roku 2011 posouvá $\mathrm{k}$ vyšším hodnotám, a sice od 85,8 do 143,7. V podstatě se jedná o interval odpovídající výše vymezeným obcím okresu Hodonín, jehož podmnožinou je interval hodnot indexu stáŕí pro obce okresu Břeclav $(99,0$ - 133,7). Relativní změna indexu stáŕí obcí okresu Břeclav se pohybuje v rozmezí od 53,9 do $151,9 \%$, v okresu Hodonín se jedná o rozmezí od 41,9 do 198,5 \%. Současné hodnoty indexu stáríi i jeho změna na úrovni jednotlivých obcí jsou taktéž více diferencované v př́ípadě okresu Hodonín.

Jelikož do indexu stáŕí vstupuje rovnocenně s poproduktivní složkou obyvatelstva isložka předproduktivní, je vhodné alespoň rámcově sledovat tyto komponenty odděleně. Ke zjištění rozsahu, v němž jednotlivé komponenty indexu stáří přispívají k jeho konečné hodnotě, stačí v nejjednodušším pojetí sledovat pouze věkovou skupinu obyvatel 65 let a starších. 
Obr. 3: Změna v zastoupení poproduktivní složky obyvatelstva venkovských obcí JMK (1991-2011)

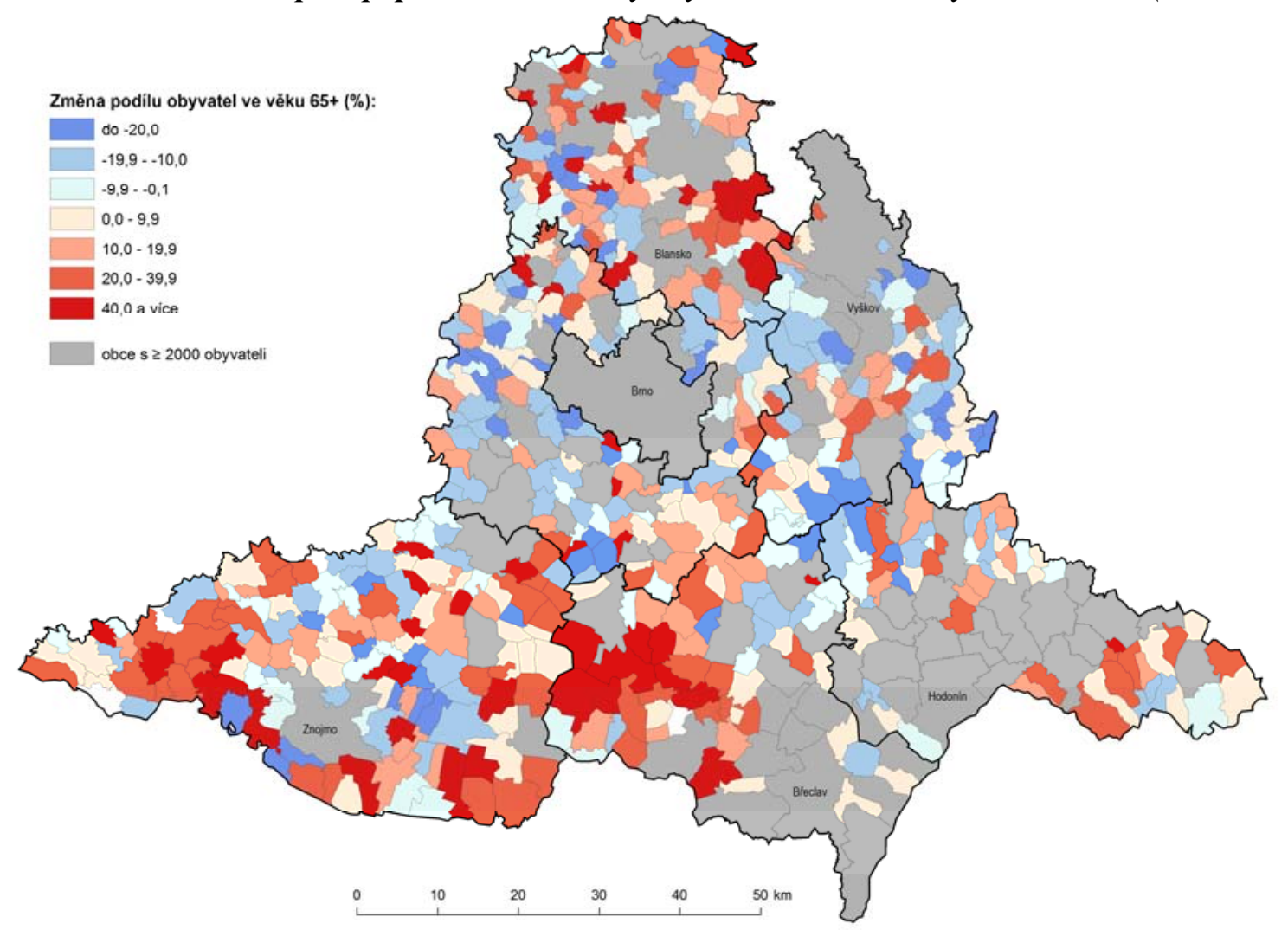

Zdroj: ČSÚ - SLDB 1991, SLDB 2001, předběžné výsledky SLDB 2011, vlastní zpracování

Ve srovnání s dynamikou vývoje indexu stáří se změny zastoupení poproduktivní složky v populaci venkovských obcí JMK jeví jako méně výrazné, obzvláště při jednoduchém vizuálním porovnání stavů roku 1991 a 2011 (tyto kartogramy zde opět z důvodu rozsahu nefigurují). Obr. 3, který ukazuje procentní změnu zastoupení poproduktivní složky, však určité posuny zachycuje. Největší nárůst relativního zastoupení obyvatel ve věku 65 a více let zaznamenaly vesměs oblasti s největším nárůstem indexu stáríi, a sice západní a jižní část okresu Znojmo, západní polovina okresu Břeclav a jihovýchod okresu Blansko. S nejvýraznějším poklesem podílu poproduktivní složky na populaci je možné se ve větší míře setkat zejména v okresech Brno-venkov a Vyškov. Na základě tab. 3 lze nicméně prohlásit, že změna podílu poproduktivní složky na celkovém počtu obyvatel není ve srovnání s vývojem indexu stáří natolik významná. Postavení dětské složky v populaci však zažívá výrazný pokles způsobující nepřehlédnutelné změny indexu stárí, které např. Kalibová a kol. (2009) interpretuje jako stárnutí odspodu věkové pyramidy. Současně narůstá zastoupení produktivní složky venkovského obyvatelstva, za nímž podle všeho stojí suburbanizační tlaky a obecně také dospívání dětí narozených od druhé poloviny 70 . let.

Tab. 3: Zastoupení hlavních věkových skupin v populaci venkovských obcí JMK

\begin{tabular}{|l|c|c|c|c|c|c|}
\hline & \multicolumn{2}{|c|}{ Věková struktura v roce 1991} & \multicolumn{3}{c|}{ Věková struktura v roce 2011} \\
\hline Věková skupina & $0-14$ & $15-64$ & $65+$ & $0-14$ & $15-64$ & $65+$ \\
\hline Počet obyvatel dané věkové skupiny & 66570 & 202336 & 46248 & 51625 & 235518 & 51716 \\
\hline Podíl na celkové populaci (\%) & 21,1 & 64,2 & 14,7 & 15,2 & 69,5 & 15,3 \\
\hline
\end{tabular}

Zdroj: ČSÚ - SLDB 1991, SLDB 2001, předběžné výsledky SLDB 2011, vlastní zpracování

Vliv suburbanizace potvrzuje i obr. 3, z něhož je patrná odlišnost vývoje mezi venkovským zázemím měst a zbytkem prostoru. Nejvíce poklesl relativní význam věkové skupiny starších 65 let v širším zázemí Brna, a dále také v zázemí Znojma. Pro tyto oblasti je zároveň př́značný příznivý vývoj indexu stárí, způsobený usazováním rodin s dětmi či plánujících potomstvo, což je také v souladu s výrazně pozitivním vývojem počtu obyvatel. V ostatních venkovských oblastech vesměs současně 
s růstem podílu věkové skupiny starších 65 let dochází k nárůstu hodnot indexu stáríi, čemuž odpovídá i úbytek obyvatel. Regionální diferenciace vývoje věkové struktury tedy v př́padě venkovských oblastí JMK v rozhodující míře souvisí $\mathrm{s}$ prostorovým průběhem migrace produktivní složky obyvatelstva a rozložením porodnosti v prostoru i čase, až druhotně se jedná o prostorové rozdíly ve změně zastoupení poproduktivní složky v populaci.

\section{Venkov v zázemí okresních měst}

Jak již bylo několikrát naznačováno výše, pro venkovské obce, které se nachází v blízkosti okresních měst (zejména Brna), se charakter demografického vývoje zdá být zcela odlišný než pro zbytek venkovských obcí, což nyní bude oveř̌eno na konkrétním souboru obcí. Následující kartogram (obr. 4) zachycuje prostorovou diferenciaci denní vyjížd'ky za prací z venkovských obcí. Za venkovské zázemí okresních měst (př́íměstský venkov) jsou považovány obce, z nichž denně vyjíždí $40 \%$ trvale bydlících zaměstnaných a více (celkem 96 obcí, které v roce 1991 představovaly 17,7\% celkového počtu venkovských obcí a $21,9 \%$ venkovského obyvatelstva JMK, průměrná velikost obce byla 719 obyvatel). Tyto obce tvoří zázemí zejména Brnu, ale také Znojmu, Blansku a Vyškovu. Určité náznaky je možné pozorovat i v okolí Břeclavi a Hodonína. Odděleně je sledována také skupina obcí s vyjížd'kou nižší než $10 \%$ (celkem 169 obcí, tvořících v roce 1991 31,2 \% celkového počtu venkovských obcí a $27 \%$ venkovského obyvatelstva JMK, průměrná velikost obce byla 503 obyvatel), kterou je možné nazvat odlehlým venkovem. Užití termínu mezilehlý venkov pro soubor venkovských obcí s vyjížd'kou v intervalu 10-39,9\% svým způsobem ilustruje základní možnost uchopení typologie venkovských oblastí, obecně definované ve Strategii regionálního rozvoje ČR na roky 2007-2013, která na základě polohy vůči urbanizovaným oblastem, dopravní dostupnosti a ekonomických znaků rozlišuje právě venkov příměstský, mezilehlý a odlehlý. Do kategorie mezilehlého venkova zde spadá 277 obcí, což bylo v roce 1991 51,1 \% celkového počtu venkovských obcí, v nichž žilo $51,1 \%$ venkovského obyvatelstva JMK, přičemž průměrná velikost obce byla 582 obyvatel. 
Obr. 4: Denní vyjižd'ka za prací do okresních měst (2001)

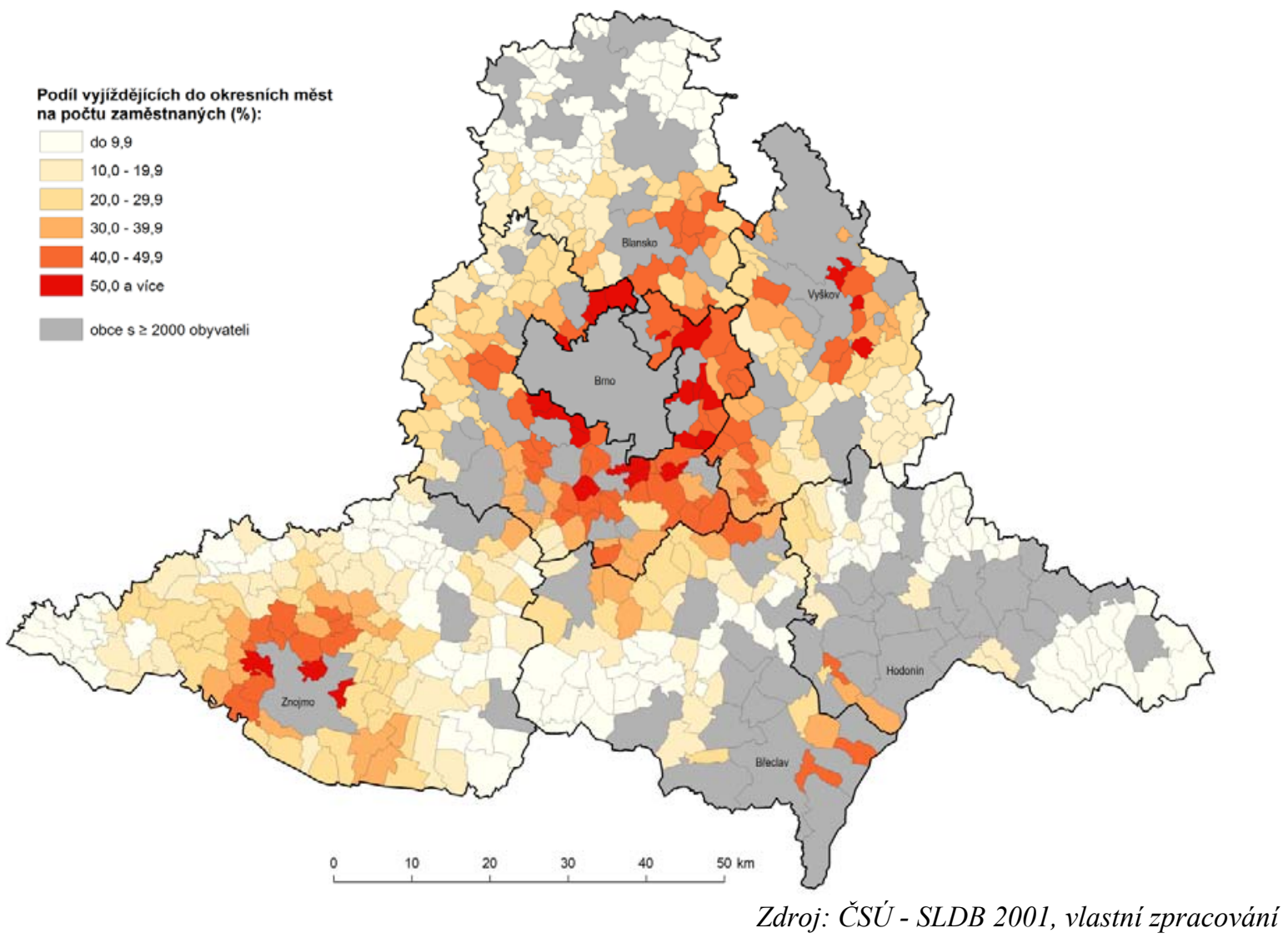

$\mathrm{Z}$ tab. 5 je zřejmé, že vývoj počtu obyvatel i věkové struktury velmi úzce (téměř přímo úměrně) souvisí s polohou obcí v sídelním systému a úrovní interakce s jeho významnými centry. Při pohledu na vývoj počtu obyvatel je vidět, že ze sledovaných kategorií nejvíce obyvatel získaly (jak relativně, tak absolutně) obce príměstského venkova s vyjížd’kou přesahující $40 \%$. Obce náležící do kategorie odlehlého venkova s vyjížd'kou menší než 10 \% naopak utrpěly mírnou populační ztrátu.

Tab. 5: Demografický vývoj venkova JMK v závislosti na intenzitě vyjižd'ky za prací

\begin{tabular}{|c|c|c|c|c|}
\hline \multicolumn{5}{|c|}{ Vývoj počtu obyvatel } \\
\hline Venkovské obce JMK dle denní vyjižd'ky za prací: & 1991 & 2001 & 2011 & Změna 1991-2011 (\%) \\
\hline$\geq 40 \%$ & 69002 & 70720 & 81973 & 18,8 \\
\hline $10-39,9 \%$ & 161092 & 162886 & 172364 & 7,0 \\
\hline$<10 \%$ & 85059 & 83502 & 84520 & $-0,6$ \\
\hline \multicolumn{5}{|c|}{ Vývoj indexu stáří } \\
\hline$\geq 40 \%$ & 74,5 & 91,5 & 94,7 & 27,1 \\
\hline $10-39,9 \%$ & 69,3 & 83,2 & 99,8 & 44,0 \\
\hline$<10 \%$ & 66,0 & 81,3 & 106,8 & 61,8 \\
\hline \multicolumn{5}{|c|}{ Vývoj podílu věkové skupiny $65+$} \\
\hline$\geq 40 \%$ & 15,1 & 15,1 & 15,2 & 0,1 \\
\hline $10-39,9 \%$ & 14,7 & 14,6 & 15,2 & 3,2 \\
\hline$<10 \%$ & 14,2 & 14,1 & 15,5 & 9,1 \\
\hline
\end{tabular}

Zdroj: ČSÚ - SLDB 1991, SLDB 2001, predběžné výsledky SLDB 2011, vlastní zpracování

Index stáří se nejplynuleji vyvíjel v nejpočetněji zastoupené kategorii obcí s vyjižd'kou mezi 10 a 39,9\%. Rozdíly ve vývoji indexu stáŕi se projevily až v posledním desetiletí, kdy se stárnutí př́městského venkova znatelně zbrzdilo vlivem důsledků již dříve popsané suburbanizace, zatímco stárnutí odlehlého venkova naopak akcelerovalo a poproduktivní složka populace převážila složku předproduktivní. Relativní význam věkové skupiny starších 65 let v případě odlehlého venkova 
výrazně narůstá, oproti stagnaci v kategorii příměstského venkova, kde se sice zvyšuje absolutní počet starších 65 let, tento nárůst je však relativně smazáván jednak růstem počtu obyvatel produktivního věku a v posledním desetiletí také oživením vývoje dětské složky populace.

\section{Závěr}

Výsledky výzkumu, jehož cílem bylo analyzovat prostorovou diferenciaci demografického vývoje venkovských oblastí Jihomoravského kraje, ukazují, že tyto oblasti v souhrnu během sledovaného období (1991-2011) výrazně populačně rostou, což se děje zejména vlivem suburbanizace, která ve druhé dekádě sledovaného období zrychluje. Kategorie nejmenších obcí (do 200 obyvatel) však mezi lety 1991 a 2011 mírně ztrácí. Nejvíce obyvatel během sledovaného období prribylo ve venkovském zázemí Brna, Blanska, Vyškova a Znojma, zatímco nejvýraznější úbytek obyvatel se odehrál na severozápadě a západě okresu Blansko, v severní a západní části okresu Znojmo, ve východní části okresu Hodonín a v jihovýchodní části okresu Vyškov.

Populace stárne v celém sledovaném území bez výjimky. Jak dynamika stárnutí obyvatelstva ve sledovaném období, tak i současné hodnoty indexu stáří se liší v závislosti na kategorizaci venkovských obcí dle populační velikosti. Přes výrazné změny indexu stáří ve sledovaném období zůstává ve venkovském prostoru předproduktivní a poproduktivní složka obyvatelstva vyrovnaná, zejména zásluhou obcí nad 200 obyvatel. Důvodem je pravděpodobně vliv suburbanizace v zázemí větších měst, zejména Brna. Nejvyššího indexu stáří v současnosti dosahují nejmenší venkovské obce do 200 obyvatel a zároveň města. Obou kategorií se v minulosti znatelně dotkla silná urbanizace (a její následný vliv na přirozenou dynamiku obyvatel), a to tím způsobem, že města byla v roce 1991 ,plná mladých obyvatel“" které přitahovala $\mathrm{z}$ venkovského prostoru, přičemž venkovské oblasti byly o tyto obyvatele ochuzeny. Ve spojení s akcelerující suburbanizací se ve vývoji věkové struktury městského obyvatelstva objevil nepřehlédnutelný výkyv, zatímco do nejmenších obcí suburbanizace zasáhla pouze $\mathrm{v}$ omezené miŕre. $\mathrm{Z}$ analýzy změn věkové struktury na úrovni obcí vyplynulo, že nejméně zestárlo venkovské obyvatelstvo okresů Brno-venkov a Vyškov, zejména díky výraznému zpomalení růstu indexu stáŕí v posledním desetiletí. V největším rozsahu naopak probíhal proces demografického stárnutí ve venkovských oblastech západní poloviny okresu Břeclav, západní a jihovýchodní části okresu Znojmo, severní a jihovýchodní části okresu Hodonín a méně jednotně také v okresu Blansko. Tento proces je kumulován zejména $\mathrm{v}$ jižní části kraje. Ukázalo se, že regionální diferenciace demografického stárnutí $\mathrm{v}$ príípadě JMK silněji souvisí s migrací produktivní složky obyvatelstva, resp. rodin $\mathrm{s}$ dětmi, a rozložením porodnosti $\mathrm{v}$ prostoru, než $\mathrm{s}$ růstem podílu poproduktivního obyvatelstva.

Odděleně bylo zkoumáno zázemí okresních měst Jihomoravského kraje, které bylo vymezeno na základě intenzity vyjížd'ky za zaměstnáním z obce do okresních měst. Bylo prokázáno, že demografický vývoj venkovských oblastí velmi úzce souvisí s polohou v rámci sídelního systému, přičemž venkovské obce $\mathrm{v}$ zázemí měst během sledovaného období výrazně populačně rostly a nejméně se potýkaly s problémem demografického stárnutí, naopak obce odlehlého venkova obyvatelstvo mírně ztratily a stárnutím byly zasaženy mnohem výrazněji. Dá se říci, že dynamika indexu stáři je $\mathrm{v}$ rámci uvažovaných kategorií příměstského, mezilehlého a odlehlého venkova nepřímo úměrná intenzitě vyjížd'ky za prací do okresních měst. V souladu s obecnou povahou procesu suburbanizace v zázemí měst růst indexu stáři zpomaluje, zatímco v odlehlých venkovských oblastech naopak akceleruje, současně $\mathrm{s}$ výraznějším nárůstem relativního významu poproduktivní složky obyvatelstva. Poloha obcí v rámci sídelního systému a s ní související rozsah interakce s centry jednoznačně souvisí s regionální diferenciací demografického vývoje venkovských oblastí.

Z provedených analýz v souhrnu vyplývá, že kumulace negativních aspektů demografického vývoje je př́značná zejména pro jižní část kraje, vyznačující se nízkou mírou interakce s okresními městy a silnou tradicí zemědělství, které prošlo výraznou transformací, spojenou s růstem nezaměstnanosti. Uvedené závěry zčásti korespondují s hodnocením Hampla (2005), který v rámci ČR řadí všechny okresy JMK s výjimkou okresu Brno-město do nejnižší kategorie ekonomické úrovně, s kumulací 
nezaměstnanosti zejména $\mathrm{v}$ jižní polovině kraje. Fakt, že se jižní část kraje řadí mezi nejvíce postižené oblasti ČR, potvrzují také data o nezaměstnanosti, uvedená ve Statistické ročence JMK 2010.

Existuje řada dalších faktorů, které mohou souviset $\mathrm{s}$ prostorovou diferenciací demografického vývoje. Např. doprava má podle Binka a kol. (2007) zásadní vliv na formování sídelního systému daného území a udržitelnost venkovského prostoru. Lze se domnívat, že podél hlavních dopravních tahů existuje vyšší potenciál $\mathrm{k}$ přenosu rozvojových impulsů do venkovského prostoru. Vaishar a kol. (2008) naznačuje, že dobře dostupný venkov je mnohem náchylnější $\mathrm{k}$ postupné transformaci do podoby širšího urbanizovaného prostoru, $\mathrm{v}$ němž se prolínají tradiční venkovské znaky se znaky městskými. Některé souvislosti, pro jejichž bližší interpretaci zde již není prostor, lze odvodit z pouhého překrytí dopravní sítě JMK s kartogramem změny počtu obyvatel ve venkovských obcích.

\section{Literatura}

[1] BEVAN, M. Planning for an Ageing Population in Rural England: The Place of Housing Design. Planning, Practice \& Research, 2009, Vol. 24 (2): s. 233-249. DOI: 10.1080/02697450902827386.

[2] BINEK, J., GALVASOVÁ, I., HALÁSEK, D., KUNC, J., ŘEHÁK, S., SEIDENGLANZ, D., TOUŠEK, V., VĚŽNÍK, A. Venkovský prostor a jeho oživení. Brno, 2007. 1. vyd. $140 \mathrm{~s}$.

[3] BURCIN, B., FIALOVÁ, L., RYCHTAŘíKOVÁ, J. a kol. Demografická situace České republiky: Proměny a kontexty 1993-2008. Praha: Sociologické nakladatelství, 2010. 1. vyd. 238 s.

[4] CLOKE, P. An index of rurality for England and Wales. Regional Studies, 1977, 2 (1): 31-46.

[5] CLOKE, P. The countryside. In Policy and Change in Thatcher's Britain. Oxford Pergamon, 1992. s. 269-296.

[6] Český statistický úruad: Databáze demografických údajů za obce ČR. [online, cit. 13. 1. 2013] Dostupné z: <http://www.czso.cz/cz/obce_d/index.htm>.

[7] Český statistický úr̆ad: Postavení venkovā v Jihomoravském kraji 2009. [online, cit. 8. 5. 2012] Dostupné z: <http://notes3.czso.cz/csu/2009edicniplan.nsf/krajp/641361-09-xb>.

[8] Český statistický úřad. Sčítání lidu, domů a byti̊ 1991.

[9] Český statistický úřad. Sčítání lidu, domů a byti̊ 2001.

[10] Český statistický úrad. Sčitání lidu, domů a bytio 2011, predběžné výsledky.

[11] Český statistický úřad. Statistická ročenka Jihomoravského kraje 2010. [online, cit. 8. 5. 2011] Dostupné z: <http://czso.cz/csu/2010edicniplan.nsf/krajp/641011-10-xb>.

[12]Č́TRNÁCT, P., MARYÁŠ, J. Vývoj obyvatelstva ČSSR v letech 1961-1980. Sborník Československé geografické společnosti, roč. 1993, č. 3, s. 162-168.

[13] GREEN, B. Countryside conservation. London, Unwin Hyman, 1990.

[14]HAMPL, M. Geografická organizace společnosti v České republice: Transformační procesy a jejich obecný kontext. DemoArt Praha, 2005. $147 \mathrm{~s}$.

[15] HOGGART, K. Let's do away with rural. Journal of Rural Studies, 1990, 6: 245-257. DOI: 10.1016/0743-0167(90)90079-N.

[16] KALIBOVÁ, K., PAVLÍK, Z., VODÁKOVÁ, A. Demografie (nejen) pro demografy. Praha: Sociologické nakladatelství, 2009. 3. vyd. $241 \mathrm{~s}$.

[17] KORNAI, J. The great transformation of Central Eastern Europe: Success and disappointment. Economics of Transition, 2006, Vol. 14 (2): s. 207-244. DOI: 10.1111/j.14680351.2006.00252.x.

[18] KUNC, J., SYNKOVÁ, L. Brněnská př́iměstská oblast: př́íklad jejího vymezení. In Klímová, V. (ed.) XIII. mezinárodní kolokvium o regionálnich vědách. Sborník přispěvků. Brno: Masarykova univerzita, 2010. s. 284-290.

[19]MARYÁŠ́, J., ŘEHÁK, S. Depopulation of rural areas in the Czech Republic. In The processes of depopulation of rural areas in Central and Eastern Europe. Warszawa: Institut of Geography and Spatial Organisation, Polish Academy of Science, 1990. s. 221-235.

[20]PAŘIL, V. Zapojení obcí v mikroregionech České republiky. In Klímová, V., Žítek, V. (eds.) $X I V$. mezinárodni kolokvium o regionálních vědách. Sborník př́spěvkù. Brno: Masarykova univerzita, 2011. s. 206-215. 
[21]PATMORE, J.A. Recreation and Resources: Leisure Patterns and Leisure Places. Oxford: Blackwell, 1983.

[22]PAVLÍK, Z., RYCHTAŘíKOVÁ, J., ŠUBRTOVÁ, A. Základy demografie. Československá akademie věd, Academia Praha, 1986. 1. vyd. 736s.

[23] PERLÍN, R. Venkov, typologie venkovského prostoru. Praha. Ministerstvo vnitra, 1998. [online, cit. 8. 2. 2012] Dostupné z: <http://aplikace.mvcr.cz/archiv2008/odbor/reforma/perlin.pdf $>$.

[24]PETR, O. Širší souvislosti vývoje plodnosti ve vybraných evropských zemích. In Klímová, V. (ed.) XIII. mezinárodni kolokvium o regionálnich vědách. Sbornik př́spěvků. Brno: Masarykova univerzita, 2010. s. 307-319.

[25] ROBINSON, G.M. Conflict and Change in the Countryside. London, Belhaven Press, 1990.

[26] SCHARF, T. Ageing and intergenerational relationships in rural Germany. Ageing and Society, 2001, Vol. 21: s. 547-566.

[27] SRB, V. 1000 let obyvatelstva českých zemí. Praha: Karolinum, 2004. 1. vyd. 276 s.

[28] Strategie regionálního rozvoje České republiky na obdobi 2007-2013. Ministerstvo pro místní rozvoj ČR. Praha, 2006. $221 \mathrm{~s}$.

[29] TOUŠEK, V., SMOLOVÁ, I., FŇUKAL, M. a kol. Česká republika: Portréty krajů. Ministerstvo pro místní rozvoj ČR, 2006. $136 \mathrm{~s}$.

[30] VAISHAR, A., FRANTÁL, B., KALLABOVÁ, E., KIRCHNER, K., KLAPKA, P., LACINA, J., MARTINÁT, S., ZAPLETALOVÁ, J. Geografie malých měst a jejich úloha v systému osídlení. Studia geographica 99. Ústav geoniky Akademie věd ČR, Brno 2008. 108 s.

[31] VITURKA, M. Nový př́stup k hodnocení disparit v regionálním rozvoji. In Klímová, V. (ed.) XIII. mezinárodni kolokvium o regionálních vědách. Sborník př́spěvků. Brno: Masarykova univerzita, 2010. s. 25-32.

Př́spěvek byl zpracován v rámci specifického výzkumu na vysoké škole pod označením MUNI/A/0749/2012 - Ekonomické př́nosy cestovního ruchu pro regionální a lokální ekonomiku. 